\title{
The Relationship between Working Capital Management and Profitability: Evidence in Viet Nam
}

\author{
Le Duc Toan ${ }^{1}$,Ho Van Nhan ${ }^{2}$, Le Nguyen Ngoc $\mathrm{Anh}^{3} \&$ Le Quang Man ${ }^{4}$ \\ ${ }^{1}$ Duy Tan University, Viet Nam \\ ${ }^{2}$ Ph. D, Graduate School, Duy Tan University, Da Nang City, Viet Nam \\ ${ }^{3}$ Fellow Ph.D., La Trobe University, Australia \\ ${ }^{4}$ Finance-Marketing University, Ho Chi Minh City, Vietnam \\ Correspondence: Le Duc Toan, Associate Professor, Ph. D, Deputy Director, Duy Tan University, Da Nang City, \\ Viet Nam. E-mail: leductoan2002@gmail.com
}

Received: April 19, 2017

Accepted: June 21, 2017

Online Published: July 18, 2017

doi:10.5539/ijbm.v12n8p175

URL: https://doi.org/10.5539/ijbm.v12n8p175

\begin{abstract}
This study is aimed at explaining relationship between working capital management and profitability with Vietnam empirical evidence. We selected a sample of 34 construction companies listed in the Vietnam stock exchange for the period of $2007-2015$. We found statistically significant negative relationship between the cash conversion cycle with profitability and also found statistically significant positive relationship between the debt ratio and the fixed financial assets ratio with construction companies' profitability. The results have the special meaning to construction companies in which Vietnamese construction companies doing business in the Vietnamese economy have their own characteristics.
\end{abstract}

Keywords: working capital management, profitability, cash conversion cycle, debt ratio, sale growth

\section{Introduction}

Working Capital includes the whole current assets owned by a firm. Suitable finance strategy can bring efforts for firm, finance director implements to carry the balance between current assets not at optimal level and responsibilities to an optimal level (Lamberson, 1995). To raise the market value, firms need to build the efficient capital management strategy (Howorth \& Westhead, 2003; Deloof, 2003; Afza \& Nazir, 2007).

Firms with the competent financial directors in managing receivables, inventories and liabilities can be successful and bring business efficiency (Filbeck \& Krueger, 2005). The optimum working capital level is the case in which balance between risk and efficiency is provided. Working capital management has its effect on liquidity as well on profitability of this firm (Raheman, 2007).

Working capital management directly influences profitability and liquidity position of firms also confirms the important role of working capital management (Nobannee, 2011). Kienschnick et al., (2006) stated that an additional dollar invested in working capital would be less than a dollar, indeed. Shortening receivable conversion cycle and inventory conversion period can improve firm's profitability (Mansoori and Muhammad, 2012)

\section{Literature Review}

Most of the previous financial literatures unify important role in managing working capital. The research result of Shin \& Soenen (1998) and Teruel \& Solano (2007) found that there is a negative relationship between profitability of a firm and cash conversion cycle. Thus, financial director can raise firm's profitability by more efficient working capital management. Firms can strengthen their funding capabilities or decrease the source cost that they divide to current assets. To realize this, financial directors need to allocate main elements of cash conversion cycle (short term trade liabilities, short term account receivables and inventories) in a financial plan that they maximize firm's profitability.

Raheman \& Nasr (2007) studied 94 Pakistan firms listed on Karachi Stock Exchange for a period of $1999-2004$. The results show that there is a strong negative relationship between variables of the working capital management and profitability of the firm. It means that as the cash conversion cycle increases it will lead to 
decreasing profitability of the firm, and managers can create a positive value for the shareholders by reducing the cash conversion cycle to a possible minimum level. The study shows that there is a significant negative relationship between liquidity and profitability. There is also a significant negative relationship between debt used by the firm and its profitability. The study also finds that there is a positive relationship between size of the firm and its profitability.

Lazadizis \& Tryfonidis (2006) used a sample of 131 companies listed on the Athens Stock Exchange (ASE) for the period of $2001-2004$. The results found that there is statistical significance between profitability, measured through gross operating profit, and the cash conversion cycle. Moreover management can create profits for their companies by correctly handling the cash conversion cycle and keeping each different component (accounts receivables, account payables, inventory) to an optimum level.

Deloof (2003) stated that firm can increase the sales by extending cash conversion cycle but this extension of cash conversion cycle will head to the rising of working capital and the firm together bears an additional financing cost. This research was implemented with the 1,637 firms of Belgium for the period 1991-1996. The study found a significant negative relation between gross operating income and the number of days for accounts receivable, inventories and accounts payable of Belgian firms. The result shows that the negative relation between accounts payable and profitability is in line with the opinion that less profitable firms wait longer to pay their bills. The author suggests that financial director can advance firm's profitability by reducing the number of days for accounts receivable and inventories and creating the optimal strategy in managing firm's working capital.

Gill et al., (2010) researched a sample of 88 American firms listed on New York Stock Exchange for a period of 3 years from 2005 to 2007. In this study, Gill et al., (2010) used gross operating profit to gauge firm's profitability and Gill's result found that have statistically significant relationship between the cash conversion cycle and profitability. It follows that managers can create profits for their companies by handling correctly the cash conversion cycle and by keeping accounts receivables at an optimal level.

Mansoori \& Mahammad (2012) investigated the effect of working capital management on firm's profitability. He implemented panel data analysis, pooled OLS and Fixed Effect estimation, for a sample of 92 Singapore industrial firms for the period 2004 - 2011. This study suggested that financial managers can broaden profitability by managing working capital efficiently. Moreover, managers can improve firm's profitability by shortening receivable conversion period and inventory conversion period.

\section{Data and Method}

\subsection{The Characteristics of Vietnam Construction Companies and Finding Suitable Variables of This Research}

Vietnamese construction firms doing business in the Vietnamese economy have their own characteristics such as:

- The major payment method in the construction sector is a deferred payment based on the volume actually completed. In Vietnam, the payment method according to the planning progress of construction contracts is rarely applied; this method is only applied to projects with direct international funds to the project.

- The payment period for construction debts usually lasts 3-5 years, especially for the projects funded by the state budget. Therefore, construction firms have to use a lot of loans, which usually account for $80-90 \%$ of the business capital; and the construction firms are forced to seek out and execute many works in the fiscal year in order to use this work's advance capital for other works.

- Financial investments were closely linked to operation activities. They invested a lot of capital in financial assets, bought land in urban areas and cleared and leveled it for sale to people as housing or the firms themselves invest more capital to build houses, villas for sale on the market. The cost of people's land acquisition, and clearing, leveling and compensation costs for people with land acquisition often account for $10-15 \%$ of the vacant land sales price. Their activity has brought a very high profit rate, great effect compared to capital investment. Due to this, there have been many lawsuits in provinces and cities throughout the country and these lawsuits are often last many years because the land compensation rates for people with land acquisition are not suitable or too low compared to the cost that people spend acquiring other land to build houses. The Vietnamese government must take much effort to resolve these mass lawsuits; the Government has recently held public meetings and asked the provincial committees to join solving the disputes, conflicts between people with land clearance and the construction and real estate business firms.

- The Vietnam construction firms often execute works in the BT form (Build-Transfer). They buy land by the State, construct works and when completed they sell them to businesses, individuals and State agencies. 


\subsection{Selecting Variables}

With above-mentioned characteristics of Vietnam construction companies, in our study, we tried to determine the relationship between working capital management and profitability of companies listed in the Vietnam Stock Exchange. On December, $31^{\text {th }} 2015$, there are 53 construction companies listed in the Vietnam Stock Exchange but some companies were not included in the data due to lack of information for certain time. Then, our data was only selected from 306 financial reports of 34 firms that declared by public companies between January 1, 2007 and December 31, 2015. The variables and calculation method are given in Table 1.

Table 1. Dependent and independent variables

\begin{tabular}{llll}
\hline Variables Symbol & Variables Name & Calculation Methods & $\begin{array}{l}\text { Predicted } \\
\text { sign }\end{array}$ \\
\hline GOP & Gross Operating Profit & (Sales - Cost of Goods Sold)/ Total Assets & - \\
ARP & Accounts Receivable Period & $365 /($ Net Sales/Short-Term Accounts & Receivables) \\
& & $365 /($ Selling Cost/Accounts Payable) & - \\
APP & Accounts Payable Period & 365/(Selling Cost/Inventories) & - \\
AIP & Accounts Inventory Period & (ARP + AIP) - APP & $+/+$ \\
CCC & Cash Conversion Cycle & Fixed Financial Assets/Total Assets & + \\
FATA & Fixed Financial Assets Ratio & (Short Term Loans + Long Term Loans)/Total assets & + \\
\hline FD & Financial Debt Ratio & (This year's sales- Previous year's sales)/ Previous & + \\
GROWTH & Sales growth & year's sales & \\
\hline
\end{tabular}

We studied the relationship between gross operating profit (GOP) and working capital management of firms through four models as below:

Model (1)

$$
\mathrm{GOP}_{\mathrm{it}}=\beta_{1 \mathrm{it}}+\beta_{2 \mathrm{it}} \mathrm{ARP}_{2 \mathrm{it}}+\beta_{3 \mathrm{it}} \mathrm{GROWTH}_{3 \mathrm{it}}+\beta_{4 \mathrm{it}} \mathrm{FD}_{4 \mathrm{it}}+\beta_{5 \mathrm{it}} \mathrm{FATA}_{5 \mathrm{it}}+\varepsilon_{1}
$$

Model (2)

Model (3)

$$
\mathrm{GOP}_{\mathrm{it}}=\beta_{1 \mathrm{it}}+\beta_{2 \mathrm{it}} \mathrm{AIP}_{2 \mathrm{it}}+\beta_{3 \mathrm{it}} \mathrm{GROWTH}_{3 \mathrm{it}}+\beta_{4 \mathrm{it}} \mathrm{FD}_{4 \mathrm{it}}+\beta_{5 \mathrm{it}} \mathrm{FATA}_{5 \mathrm{it}}+\varepsilon_{1}
$$

Model (4)

$$
\mathrm{GOP}_{\mathrm{it}}=\beta_{1 \mathrm{it}}+\beta_{2 \mathrm{it}} \mathrm{APP}_{2 \mathrm{it}}+\beta_{3 \mathrm{it}} \mathrm{GROWTH}_{3 \mathrm{it}}+\beta_{4 \mathrm{it}} \mathrm{FD}_{4 \mathrm{it}}+\beta_{5 \mathrm{it}} \mathrm{FATA}_{5 \mathrm{it}}+\varepsilon_{1}
$$

$$
\mathrm{GOP}_{\mathrm{it}}=\beta_{1 \mathrm{it}}+\beta_{2 \mathrm{it}} \mathrm{CCC}_{2 \mathrm{it}}+\beta_{3 \mathrm{it}} \mathrm{GROWTH}_{3 \mathrm{it}}+\beta_{4 \mathrm{it}} \mathrm{FD}_{4 \mathrm{it}}+\beta_{5 \mathrm{it}} \mathrm{FATA}_{5 \mathrm{it}}+\varepsilon_{1}
$$

\subsection{Descriptive Statistics}

Descriptive statistics of the collected variables as Table 2.

Table 2. Descriptive statistics

\begin{tabular}{lcccccccc}
\hline & GOP & ARP & AIP & \multicolumn{1}{l}{ APP } & CCC & GROWTH & FD & FATA \\
\hline Mean & 0.11463 & 205.7181 & 194.7432 & 247.0461 & 153.4152 & 0.264217 & 0.367680 & 0.086197 \\
Median & 0.08632 & 152.4681 & 147.3609 & 213.3128 & 111.9361 & 0.125786 & 0.361744 & 0.043919 \\
Maximum & 1.03327 & 734.0149 & 951.1344 & 1120.544 & 1049.242 & 17.18667 & 0.938417 & 0.957021 \\
Minimum & -0.04424 & 18.14802 & 11.61393 & 8.395747 & -179.7055 & -2.625226 & 0.000921 & 0.000000 \\
Std. Dev. & 0.10357 & 154.6608 & 158.2217 & 173.4035 & 168.3685 & 1.289474 & 0.238173 & 0.122159 \\
Skewness & 3.241176 & 1.345285 & 1.779417 & 1.545791 & 1.921900 & 8.332548 & 0.311423 & 3.048085 \\
Kurtosis & 23.47360 & 4.292655 & 7.326848 & 6.640274 & 9.029216 & 102.2390 & 2.083370 & 16.84282 \\
Jarque-Bera & 5880.160 & 113.6041 & 400.1831 & 290.8208 & 651.8597 & 129107.9 & 15.65889 & 2917.033 \\
Probability & 0.000000 & 0.000000 & 0.000000 & 0.000000 & 0.000000 & 0.000000 & 0.000398 & 0.000000 \\
Sum & 35.07927 & 62949.73 & 59591.43 & 75596.10 & 46945.06 & 80.85037 & 112.5102 & 26.37634 \\
Sum Sq. Dev. & 3.27194 & 7295585. & 7635407. & 9170979. & 8646129. & 507.1369 & 17.30151 & 4.551495 \\
Observations & 306 & 306 & 306 & 306 & 306 & 306 & 306 & 306 \\
\hline
\end{tabular}


Pearson's correlation analysis for variables as Table 3

Table 3. Pearson bivariate correlation analysis

\begin{tabular}{lllllllll}
\hline & GOP & ARP & AIP & APP & CCC & GROWTH & FD & FATA \\
\hline GOP & 1 & -0.30636 & -0.19901 & -0.19241 & -0.27027 & 0.09988 & 0.26875 & 0.02204 \\
ARP & -0.30636 & 1 & 0.17396 & 0.53326 & 0.53285 & -0.15397 & -0.15331 & 0.29031 \\
AIP & -0.19901 & 0.17396 & 1 & 0.55740 & 0.52546 & -0.13447 & 0.14575 & 0.05171 \\
APP & -0.19241 & 0.53326 & 0.55740 & 1 & -0.01624 & -0.15082 & 0.45713 & 0.08904 \\
CCC & -0.27027 & 0.53285 & 0.52546 & -0.01624 & 1 & -0.11246 & -0.47466 & 0.22356 \\
GROWTH & 0.09988 & -0.15397 & -0.13447 & -0.15082 & -0.11246 & 1 & -0.00683 & 0.00440 \\
FD & 0.26875 & -0.15331 & 0.14575 & 0.45713 & -0.47466 & -0.00683 & 1 & -0.20905 \\
FATA & 0.02204 & 0.29031 & 0.05171 & 0.08904 & 0.22356 & 0.00440 & -0.20905 & 1 \\
\hline
\end{tabular}

\subsection{Regression Analysis}

Implementing four regression models with the different dependent variables, the results as below:

Table 4a. Regression model estimates on factors affecting profitability

\begin{tabular}{llllll}
\hline Variable & Coefficient & Std. Error & t-Statistic & Prob & VIF \\
\hline C & 0.102695 & 0.013864 & 7.407450 & 0.0000 & \\
ARP & -0.02052 & $3.74 \mathrm{E}-05$ & -5.489032 & 0.0000 & 1.070118 \\
GROWTH & 0.043163 & 0.004271 & 1.010451 & 0.0313 & 1.032702 \\
FD & 0.111544 & 0.023447 & 4.757254 & 0.0000 & 1.031888 \\
FATA & 0.139396 & 0.047248 & 2.950287 & 0.0034 & 1.073246 \\
\hline
\end{tabular}

Method: Panel Least Squares. Dependent Variable: GOP

Independent Variables: ARP, GROWTH, FD, FATA

Total panel (balanced) observations: $306 . \mathrm{R}^{2}=0.2716$

Regression Equation: GOP $=0.1026-0.02005 \mathrm{ARP}+0.04316$ GROWTH $+0.11154 \mathrm{FD}+0.13939$ FATA

Table $4 \mathrm{~b}$. Regression model estimates on factors affecting profitability

\begin{tabular}{llllll}
\hline Variable & Coefficient & Std. Error & t-Statistic & Prob & VIF \\
\hline C & 0.084483 & 0.012909 & 6.544622 & 0.0000 & \\
AIP & -0.01591 & $3.57 \mathrm{E}-05$ & -4.444648 & 0.0000 & 1.045204 \\
GROWTH & 0.05546 & 0.004321 & 1.283613 & 0.0203 & 1.015918 \\
FD & 0.141765 & 0.024014 & 5.903417 & 0.0000 & 1.063561 \\
FATA & 0.086849 & 0.046381 & 1.872503 & 0.0621 & 1.035485 \\
\hline
\end{tabular}

Method: Panel Least Squares. Dependent Variable: GOP

Independent Variables: AIP, GROWTH, FD, FATA

Total panel (balanced) observations: $306 . \mathrm{R}^{2}=0.145038$

Regression Equation: GOP $=0.084483-0.01591 \mathrm{AIP}+0.05546$ GROWTH $+0.141765 \mathrm{FD}+0.086849$ FATA 
Table 4c. Regression model estimates on factors affecting profitability

\begin{tabular}{llllll}
\hline Variable & Coefficient & Std. Error & t-Statistic & Prob & VIF \\
\hline C & 0.085301 & 0.011692 & 7.295572 & 0.0000 & \\
APP & -0.02572 & $3.54 \mathrm{E}-05$ & -7.254014 & 0.0000 & 1.505477 \\
GROWTH & 0.03031 & 0.004138 & 0.732518 & 0.0464 & 1.025555 \\
FD & 0.21742 & 0.025949 & 8.379111 & 0.0000 & 1.526141 \\
FATA & 0.13963 & 0.045070 & 3.098066 & 0.0021 & 1.036739 \\
\hline
\end{tabular}

Method: Panel Least Squares. Dependent Variable: GOP

Independent Variables: APP, GROWTH, FD, FATA

Total panel (balanced) observations: $306 . \mathrm{R}^{2}=0.224499$

Regression Equation: GOP $=0.085301-0.02572 \mathrm{APP}+0.03031 \mathrm{GROWTH}+0.217428 \mathrm{FD}+0.13963$ FATA

Table 4d. Regression model estimates on factors affecting profitability

\begin{tabular}{llllll}
\hline Variable & Coefficient & Std. Error & t-Statistic & Prob & VIF \\
\hline C & 0.09082 & 0.015571 & 5.833113 & 0.0000 & \\
CCC & -0.01175 & $3.86 \mathrm{E}-05$ & -3.015783 & 0.0028 & 1.330858 \\
GROWTH & 0.06386 & 0.004393 & 1.453575 & 0.0147 & 1.017987 \\
FD & 0.08767 & 0.027034 & 3.242954 & 0.0013 & 1.295016 \\
FATA & 0.09002 & 0.047506 & 1.894994 & 0.0591 & 1.058388 \\
\hline
\end{tabular}

Method: Panel Least Squares. Dependent Variable: GOP

Independent Variables: CCC, GROWTH, FD, FATA

Total panel (balanced) observations: $306 . \mathrm{R}^{2}=0.115648$

Regression Equation: GOP $=0.090829-0.01175 \mathrm{CCC}+0.06386 \mathrm{GROWTH}+0.087671 \mathrm{FD}+0.09002$ FATA

In this study, we indicate the empirical results about the relationship between working capital management and profitability of the Vietnam construction companies. The results of processing in the four regression models that:

-The coefficient of ARP is significant negative, that is, the increase or decrease in ARP will opposite effect the profitability of the company. The coefficients of AIP, APP, and CCC also have significant negative with profitability.

-Having significant positive relationship between financial debt ratios with profitability of company, which means that, when leverage of the company increases, it will raise its profitability.

-The ratio of fixed financial assets to total assets also has positive affecting to profitability of the company. The coefficient of sales growth is significant positive, that is, when revenue of company rises it will impact the increasing of company's profitability.

-FATA variable has the coefficients from 0.086 to 0.1396 . The coefficient of FD variable is from 0.0876 to 0.2174 that are biggest coefficient if comparing with coefficients of other variables in four regression models. Then, FD and FATA variables have the biggest effect on company's profitability.

All the variance inflation factor (VIF) coefficients in four models are less than 2, because having no multicolinearity phenomenon. The explanation capability of four models is from $11 \%$ to $27 \%$. The alternative proxies used in this study might supply the different results with the precious studies.

\section{Conclusion}

Previous researches predicted negative relationship between ARP and GOP (Lazaridis \& Tryfonidis, 2006; Raheman \& Nasr, 2007; Gill et al., 2010; Deloof, 2003; Mathuwa, 2009), our results are consistent with these finding. The result indicates that the higher ARP, the lower profitability.

Examining the between AIP is held and profitability, Gill et al., (2010) found no significant relationship in his sample but our study found the significant negative relationship between AIP and profitability; our result is in line with the finding of Lazasidis \& Tryfonidis (2006), Raheman \& Nasr (2007), Gill et al., (2010), also found no statistically significant relationship between APP and profitability. Our result is opposite with Gill's 
result, our result expressed that less profitable companies wait longer to pay their bills. Some precious studies as Lazasidis \& Tryfonidis (2006), Garcia \& Solano (2007), Raheman \& Nasr (2007) also reported negative correlation of APP with profitability.

Previous research predicted negative relationship between CCC and profitability (Lazasidis \& Tryfonidis, 2006; Garcia \& Solano, 2007; Raheman \& Nasr, 2007; Shin \& Soenen, 1999), our result is also same. Sales growth also affects positively to company's profitability.

This paper contributes to existing literatures such as Deloof (2003), Lazaridis \& Tryfonidis (2006), Raheman \& Nasr (2007), who found negative relationship between ARP, AIP, APP with corporate profitability. We also brought negative relationship between cash conversion cycle and profitability. In addition, the characteristics of Vietnam economy were described on part of data and method, the analysis results of this study found that the construction companies in which they use debt and invest financial assets can highly raise their profitability. The findings of this research support the opinions that managers can create value for their shareholders by reducing the number of days for accounts receivable, accounts inventories and accounts payables. On the basis of this study's research, we recommend that managers can enhance company's profitability if they administrate their working capital in an optimal way.

\section{Limitations and Future Research}

There are the characteristics of Viet Nam economy, especially that capital market doesn't yet develop and doesn't strictly link between monetary with fiscal policy. In addition, the sample is limited in Vietnamese construction companies. Future research should be done in many other sectors.

\section{References}

Afza, T., \& Nazir, M. S.(2007). Is it better to be Aggressive or Conservative in Managing Working Capital? Presented at Singapore Economic Review Conference (SERC), 1-15.

Deloof, M. (2003). Does working Capital management affect profitability of Belgian firms? Journal of Business Finance \& Accounting, (30), 573-588. http://doi.org/ 10.1111/1468-5957.00008.

Filbeck, G., \& Krueger, M. T. (2005). An Analysis of Working Capital Management Results across Industries. Mid-American Journal of Business, (20), 11-20.

http://doi.org/10.1108/19355181200500007.

Garcia-Teruel, P. J., \& Martinez Solano, P. M. (2007). Effects of working capital management on SME's profitability. International of Managerial Finance, (3), 164-177. http://doi.org/10.1108/17439130710738718

Gill, A., Biger, N., \& Mathur, N. (2010). The relationship between working capital management and profitability: Evidence from The United States. Business and Economic Journal, 10, 1-9.

Howorth, C., \& Westhead, P. (2003). The focus of working Capital management in UK small firms. Management Accounting Research, (14), 94-111. http://doi.org/10.1016/S10445005(03)00022-2.

Kienschnick, R., LaPlante, M., \& Moussawi, R. (2006). Corporate working Capital management: determinants and consequences. Retrieved from http://www.fma.org/SLC/Papers/cwcmf_fma.pdf

Lamberson, M. (1995). Changes in Working Capital of Small Firms in Relation to Changes in Economic Activity. Mid-American Journal of Business, (10), 45-50.

Lazaridis, D. I., \& Tryfonidis, D. (2006). The relationship between working Capital management and profitability of listed companies in the Athens Stock Exchange. Journal of Financial Management and Analysis, (19), 1-12.

Mansoori, E., \& Mahammad, D. (2012). The effect of working capital management on firm's profitability: Evidence from Singapore. Interdisciplinary Journal of Contemporary Research Business, 5(4), 472-486.

Mathuwa, D. (2009). The influence of working capital management components on corporate profitability: a survey on Kenyan listed firms. Research Journal of Business Management, (3), 1-11.

Nobanee, H. (2009). Working Capital Management and Firm's Management: An Optimal Cash Conversion Cycle. Retrieved from hhtp://ssrm.com.abstract $=147123$

Raheman, A., \& Nasr, M. (2007). Working Capital Management and Profitability: Case of Pakistani Firms. International Review of Business Research Papers, (3), 279-300.

Shin, H., \& Soenen, L. (1998). Efficiency of working Capital management and corporate profitability. Financial 
Practice and Education, (8), 37-45.

Teruel, P. J. G., \& Solano, P. M. (2007). Effects of working Capital management on SME profitability. International Journal of Managerial Finance, (3), 164-177. http://doi.org/10.1118/17439130710738718

\section{Copyrights}

Copyright for this article is retained by the author(s), with first publication rights granted to the journal.

This is an open-access article distributed under the terms and conditions of the Creative Commons Attribution license (http://creativecommons.org/licenses/by/4.0/). 